\title{
Use of a direct-fed microbial product as a supplement during the transition period in dairy cattle
}

\author{
O. AlZahal, ${ }^{*}$ H. McGill, ${ }^{*}$ A. Kleinberg, ${ }^{*}$ J. I. Holliday,† I. K. Hindrichsen,‡ T. F. Duffield,§ and B. W. McBride ${ }^{* 1}$ \\ ${ }^{*}$ Department of Animal and Poultry Science, University of Guelph, Guelph, N1G 2W1, Canada \\ †Chr. Hansen Ltd., Milwaukee, WI 53214 \\ $\ddagger$ Chr. Hansen A/S, 2980 Hørsholm, Denmark \\ §Department of Population Medicine, University of Guelph, Guelph, N1G 2W1, Canada
}

\begin{abstract}
Two studies were conducted. The objective of the first study was to assess the effects of a direct-fed microbial (DFM) product on dry matter intake, milk yield, milk components, disease incidence, and blood metabolites in dairy cattle. The objective of the second study was to assess the effects of DFM on apparent total-tract nutrient digestibility (ATTD). One hundred twenty primiparous and multiparous Holstein cows housed in a tiestall facility at the University of Guelph were used in study 1, and a subset (21) of the same cows participated in study 2. Cows were blocked by anticipated calving date (6 blocks) and then randomly assigned within parity to receive either a DFM supplement (Chr. Hansen Ltd., Milwaukee, WI) or placebo (control). The DFM supplement provided cows with $5.0 \times 10^{9} \mathrm{cfu} / \mathrm{d}$ of 3 strains of Enterococcus faecium and $2.0 \times 10^{9} \mathrm{cfu} / \mathrm{d}$ of Saccharomyces cerevisiae. The DFM supplement was mixed with $0.5 \mathrm{~kg}$ of ground dry corn and top-dressed during the morning feeding. The placebo supplement contained the corn only. Individual feed intakes and milk yields were recorded daily. The experiment commenced 3 wk before calving and ended 10 wk postcalving. Milk samples for component analysis were collected on $3 \mathrm{~d}$ per week and pooled by week. Body weights and body condition scores were assessed $1 \mathrm{~d}$ before enrollment in the study (wk -3 ), postcalving (wk 1), and at the end of wk 3,6, and 9. Blood samples were collected before calving ( wk -3$)$ and the end of wk 1 and 3. Study 1 showed that treatment had no effect on average dry matter intake or milk yield $(\mathrm{kg} / \mathrm{d})$ over the duration of the experiment. The changes in body weights and body condition scores and net energy balance over the duration of the experiment did not differ due to treatment. Treatment had no effect on plasma concentrations of $\beta$-hydroxybutyrate, nonesterified fatty acids, glucose, or haptoglobin. Study 2
\end{abstract}

Received April 17, 2014

Accepted July 18, 2014

${ }^{1}$ Corresponding author: bmcbride@uoguelph.ca investigated the effects of DFM on ATTD of starch and neutral detergent fiber (NDF) using insoluble NDF and lignin as internal markers. Study 2 used 21 cows (block 6) from the cows that participated in study 1 while the cows were between 60 and $70 \mathrm{~d}$ in milk. Cows receiving DFM had lower fecal starch content $(0.88 \pm 0.10$ vs. $1.39 \pm 0.25)$ and greater ATTD for starch $(98.76 \% \pm$ 0.28 vs. $97.87 \% \pm 0.24)$ compared with those receiving placebo, and the AATD of NDF did not differ. Additionally, we detected no difference between internal markers for the measurement of ATTD. In conclusion, we were unable to detect a change in overall dry matter intake, milk yield, or milk and blood parameters with DFM supplementation. However, our results demonstrated that DFM can have a positive effect on total-tract starch digestibility. More studies are needed to investigate the effects of DFM and their modes of action under multiple management conditions.

Key words: direct-fed microbial, dairy cattle, transition period, starch digestibility

\section{INTRODUCTION}

Direct-fed microbial (DFM) products, defined by the USDA in 1989 as microbial-based feed additives that contain "live, naturally occurring microorganisms," have been used as feed supplements in the cattle industry for over $20 \mathrm{yr}$, mainly to enhance milk production, feed efficiency, and growth performance (Yoon and Stern, 1995; Seo et al., 2010; McAllister et al., 2011).

The main types of DFM used in ruminants studies include (1) rumen-derived bacteria that can utilize lactic acid (LUB), such as Megasphaera elsdenii, Propionibacterium freudenreichii, and Selenomonas ruminantium, or that can convert starch into end products other than lactic acid such as Prevotella bryantii 25A; (2) lacticacid producing bacteria (LAB) of intestinal origin such as bifidobacteria, lactobacilli, and enterococci; and (3) active yeast such as Saccharomyces cerevisiae (Jin et al., 2000; McAllister et al., 2011).

Early hypotheses explaining modes of action of DFM focused on improving rumen function through the mod- 
ulation of lactic acid metabolism and by promoting the growth of fiber-degrading bacteria. However, experiments in ruminants to validate those proposals are lacking. Megasphaera elsdenii, an LUB, was demonstrated in vitro to prevent the accumulation of lactic acid and thus mitigate ruminal $\mathrm{pH}$ depression (Kung and Hession, 1995). Another LUB species, Propionibacterium, has been used as a DFM. Although this bacterium is slow growing and acid intolerant, making it incapable of preventing acidosis, it is thought to improve energy status of cattle as it converts lactate to propionate (Kung, 1999). Lactic acid-producing bacteria are hypothesized to stimulate the growth of LUB by providing lactic acid as a substrate, thereby improving ruminal $\mathrm{pH}$ (Nocek et al., 2002). However, no increase in LUB within the rumen has been detected when feeding bacterial DFM. Active yeast products are the most studied DFM and they are commonly used to improve cows' performance. Active yeast is thought to scavenge traces of dissolved oxygen within the rumen, thereby creating an optimal anaerobic growth condition for fibrolytic microorganisms (Chaucheyras-Durand et al., 2008). Live yeast was also proposed to create optimal growth conditions for bacteria by preventing the accumulation of lactic acid within the rumen (Nocek, 1997). The majority of commercial products used in cattle production systems include a strain of LAB (Jin et al., 2000; McAllister et al., 2011), separately or in combination with S. cerevisiae. The justification for including a specific level of yeast in some commercial bacterial-based DFM has not been documented and it is believed that yeast is used during the manufacturing process. However, the synergy between yeast and bacterial DFM within the rumen has not been studied. Results from available studies using such products have shown inconsistent effects of DFM on DMI and milk yield (Savoini et al., 2000; Nocek et al., 2002, 2003; Nocek and Kautz, 2006; Chiquette, 2009). Recently, Chiquette et al. (2012) demonstrated a positive synergistic effect of E. faecium with S. cerevisiae or Lactococcus lactis on improving ruminal $\mathrm{pH}$ during a SARA challenge.

Based on data from different species, it has been speculated that LAB may have benefits postruminally. Those benefits may include alteration of gut microbial populations, improved diet digestibility, and improved immune function (Seo et al., 2010; McAllister et al., 2011). The mechanism involved therein has not been elucidated; however, it is thought that LAB can inhibit the growth of pathogens or competitor bacteria by producing several antimicrobials such as lactic acid (that reduces gastrointestinal $\mathrm{pH}$ ), bacteriocin (Lewenstein et al., 1979; Lauková et al., 1993; Casaus et al., 1997; Nigutova et al., 2007; Zheng et al., 2012), and hydrogen peroxide (in the presence of oxygen; Pridmore et al.,
2008). Additionally, LAB are reported to prevent the adhesion of pathogenic bacteria, such as Escherichia coli and Salmonella, to the intestinal mucus both in vivo and in vitro (Fuller, 1989; Blomberg et al., 1993; Jin et al., 2000). Additionally, the intestinal microflora has been shown to modulate both innate and acquired immune responses locally and systematically (Isolauri et al., 2001). Recently, Zheng et al. (2012) demonstrated that oral administration of Enterococcus faecium SF68 $\left(2 \times 10^{9} \mathrm{cfu} / \mathrm{kg}\right.$ of feed $)$ increased the numbers of immune cells (intraepithelial lymphocytes, goblet cells, plasma cells, and mast cells) in the small intestine of young yak. Zheng et al. (2012) concluded that Enterococcus can enhance intestinal mucosal immunity and reinforce its barrier function against infections.

The transition period is considered the most critical phase in a cow's life as it is associated with the highest incidence of metabolic disorders, as well as infections due to stress and immunodepression (Drackley, 1999). Additionally, this phase is highlighted by a significant dietary shift from high-forage-based to high-concentrate-based diets, which predisposes cows to SARA (Fairfield et al., 2007; Penner et al., 2007). Subacute ruminal acidosis is usually caused by the accumulation of VFA and, to a lesser extent, lactic acid within the rumen (Oetzel, 2000) and has been defined, using a nutritional model, as a decline in ruminal $\mathrm{pH}$ below 5.6 for approximately $300 \mathrm{~min} / \mathrm{d}$ (AlZahal et al., 2007). Symptoms of SARA are variable but often include depressed intake, resulting in poor body condition and reduced production (Plaizier et al., 2008), and may predispose cows to milk fat depression (AlZahal et al., 2009, 2010). It is well supported that depressed intake or poor ruminal conditions resulting from SARA may trigger other diseases during early lactation such as ketosis or displacements (Plaizier et al., 2008).

It has been suggested recently that feeding highstarch diets can also increase starch fermentation in the large intestine and increase the risk of hindgut acidosis (Reynolds, 2006; Li et al., 2012). Additionally, highstarch feeding has been reported to increase the presence of E. coli within the rumen (Khafipour et al., 2009b) and the large intestine (Li et al., 2011) and increase the risk of LPS translocation within the digestive tract, thereby inducing systemic inflammation (Khafipour et al., 2009a; Li et al., 2012). This translocation is likely due to impaired barrier function (Steele et al., 2011). Moreover, a recent study (Solórzano and Vale, 2011) reported that supplementing early-lactating dairy cows with DFM increased apparent total-tract digestibility of starch and improved cow performance.

The mechanism whereby DFM containing LAB may improve cow performance and gut health has not been elucidated, but it is thought that such a DFM could 
improve starch digestibility. Given the potential benefits of DFM on performance and animal health, it is believed that supplementing DFM to dairy cows during the transition period is advantageous. The objective of these studies was to investigate the effect of a DFM containing a combination of LAB and live yeast on DMI, milk parameters, blood metabolites, and apparent total-tract digestibility (ATTD) of nutrients of lactating cows during transition and early lactation.

\section{MATERIALS AND METHODS}

\section{Study 1: Effects on Production, Blood, and Health Parameters}

Animals, Treatments, and Feeding. One hundred twenty primiparous and multiparous lactating Holstein cows $(644 \pm 60 \mathrm{~kg}$ and $760 \pm 65 \mathrm{~kg}$, mean of $\mathrm{BW} \pm$ $\mathrm{SD}$; respectively) were used in a randomized block design study. We hypothesized that DFM would increase milk yield of the herd by $5 \%$ (from 35.0 to $36.7 \mathrm{~kg} / \mathrm{d}$ ). The number of animals needed to detect this difference with a coefficient of variation of $10 \%$ and a power of $80 \%$ was 60 animals per treatment (Berndtson, 1991). The numbers of primiparous and multiparous cows reflected the demographics of the herd and were 40 and 80 , respectively. Cows were enrolled in the study 3 wk before their anticipated calving date and remained in the study until wk 10 postcalving. The experiment stared in June 2011 and ended in September 2012. Cows were blocked by anticipated calving season into 6 blocks ( 25 to 32 cows each) and then randomly assigned within parity to receive a dietary supplementation regimen containing either DFM (Chr. Hansen Ltd., Milwaukee, WI) or placebo (control). Fourteen grams of the DFM supplement was mixed with $0.5 \mathrm{~kg}$ of dry ground corn, and provided a daily dose of $5 \times 10^{9} \mathrm{cfu}$ of 3 strains of Enterococcus faecium and $2 \times 10^{9} \mathrm{cfu}$ of $S$. cerevisiae (values presented as per manufacturer laboratory testing). The placebo supplement contained the carrier (corn) only. Dry cows were fed a dry-cow TMR once daily $(0800 \mathrm{~h})$ and lactating cows were fed a lactating-cow TMR twice daily (0800 and $1400 \mathrm{~h}$ ). The DFM and placebo supplements were top-dressed at $0800 \mathrm{~h}$. Sources of the DFM were obtained from the manufacturer every 3 mo, stored according to manufacturer's guidelines, and mixed with the carrier in weekly batches. The amount of offered feed was adjusted daily to allow a maximum of $5 \mathrm{~kg} / \mathrm{d}$ of orts (as-fed basis). Researchers and technical staff were blinded to the treatments.

The cows were housed in a tiestall facility at the Elora Dairy Research Station (EDRC, University of Guelph, Guelph, ON, Canada). The University of
Guelph Animal Care Committee approved their use for this experiment (animal utilization protocol \#10R105).

Experimental Measures and Samples Analyses. The cows participating in the experiment were part of the EDRC herd and were managed according to their standard operating procedures. Samples from available forages (corn silage, haylage, and hay) were collected as advised by EDRC management for chemical analysis and ration balancing. The lactating cows were offered a 1-group TMR that was balanced for $24 \mathrm{~kg}$ of DMI, $35 \mathrm{~kg}$ of milk yield, $3.8 \%$ of milk fat, and $3.25 \%$ of milk CP. The dry-cow ration was balanced for $11.5 \mathrm{~kg}$ of DMI. The ration balancing was performed using AMTS software (version 6.1, AMTS LLC, Lansing, NY). The diet balancing was performed by altering the composition of the protein supplement and the amount of forages only, without changing the type of forages used (i.e., corn silage, haylage, and hay were used throughout the experiment). Average ingredient composition $( \pm \mathrm{SD})$ of TMR and protein supplement (7 ration balances) is presented in Table 1. However, to ensure that formulated TMR met with ration-balancing targets, samples from dry-cow TMR, lactating TMR, and orts were collected 3 times per week throughout the experiment (70 wk) and frozen at $-20^{\circ} \mathrm{C}$ until analysis. The TMR and orts samples were dried for $48 \mathrm{~h}$ in a forced-air oven at $60^{\circ} \mathrm{C}$ to determine DM content for that week. Samples of both lactating and dry TMR collected within each 2 -wk period were pooled (35 pooled samples for each TMR) and analyzed (Agri-Food Laboratories Inc., Guelph, ON, Canada) for $\mathrm{CP}$, ash, ether extract, ADF (procedures 4.2.08, 4.1.10, 4.5.01, and 4.6.03, respectively; AOAC International, 1996), NDF (Mertens, 1997), soluble CP (Licitra et al., 1996), and starch concentration (Hall, 2000). Averages and standard deviations of chemical analyses of both TMR are presented in Table 1.

Amount of TMR offered (dry- and lactating-cow TMR), orts, and milk yield were recorded daily for individual cows throughout the experiment. Cows were milked twice daily at 0500 and $1500 \mathrm{~h}$, and milk samples were collected 3 times a week from morning and afternoon milkings. Milk samples were pooled by cow by day based on production, before being pooled by week using equal daily proportions, and submitted (10 weekly samples per cow) to the Laboratory Services Division (Guelph, ON, Canada) for composition analysis using a near-infrared analyzer (Foss System 4000, Foss Electric, Hillerød, Denmark).

Body weight and BCS were recorded at the beginning of the experiment ( $\mathrm{wk}-3$ ), and on the last day of wk 1, 3, 6, and 9. Body weight was recorded at $1100 \mathrm{~h}$ each day. Body condition scoring was conducted by 2 technicians using a 1-to-5 scale (Wildman et al., 1982) 
Table 1. Means $( \pm \mathrm{SD})$ of ingredient composition formulation $(\mathrm{n}=7)$ and chemical analysis $(\mathrm{n}=35)$ of dry cow and lactating cow TMR

\begin{tabular}{|c|c|c|}
\hline Item & Dry cow & Lactating cow \\
\hline \multicolumn{3}{|l|}{ Ingredient, $\%$ of DM } \\
\hline Corn silage & $45 \pm 5$ & 26 \\
\hline Alfalfa silage & $11 \pm 3$ & 26 \\
\hline Straw & $27 \pm 2$ & 6 \\
\hline High-moisture corn & - & $20 \pm 1$ \\
\hline Protein supplement $^{1}$ & $18 \pm 2$ & 21 \\
\hline \multicolumn{3}{|c|}{$\begin{array}{l}\text { Chemical composition, \% of DM } \\
\text { (unless otherwise noted) }\end{array}$} \\
\hline DM, $\%$ & $44 \pm 3$ & $45 \pm 3.6$ \\
\hline $\mathrm{CP}(\mathrm{N} \times 6.25)$ & $13 \pm 1$ & $16 \pm 1$ \\
\hline Soluble protein & $5 \pm 1$ & $6 \pm 2$ \\
\hline NDIN & $3 \pm 1$ & $4 \pm 1$ \\
\hline $\mathrm{ADF}$ & $31 \pm 3$ & $23 \pm 2$ \\
\hline $\mathrm{NDF}$ & $46 \pm 3$ & $34 \pm 3$ \\
\hline $\mathrm{NFC}^{2}$ & $34 \pm 3$ & $43 \pm 3$ \\
\hline Starch $^{3}$ & $18 \pm 3$ & $22 \pm 3$ \\
\hline Ether extract & 3 & 3 \\
\hline Lignin & $5 \pm 1$ & $5 \pm 1$ \\
\hline Ash & $8 \pm 1$ & $7 \pm 1$ \\
\hline $\mathrm{NE}_{\mathrm{L}},{ }^{4} \mathrm{Mcal} / \mathrm{kg}$ & $1.37 \pm 0.04$ & $1.68 \pm 0.04$ \\
\hline
\end{tabular}

${ }^{1}$ Dry cow protein supplement contained (as-fed basis, mean $\pm \mathrm{SD}$ ): $48 \%$ soybean meal, $51 \pm 2 \%$; canola meal, $10 \%$; wheat bran, $10 \%$; vitamin and mineral mix, $19 \pm 1 \%$; soybean hulls, $4 \pm 2 \%$; molasses, $2 \%$; and tallow, $3 \%$. Lactating cow supplement contained (as-fed basis, mean $\pm \mathrm{SD}$ ): high-protein corn gluten meal, $9 \pm 4 \%$; $48 \%$ soybean meal, $30 \pm 4 \%$; Tri-Pro Gold (Tri-County Protein Corp., Winchester, ON, Canada), $7 \pm 5 \%$; canola meal, $14 \pm 4 \%$; beet pulp, $10 \%$; herring meal, $3 \%$; dry corn distillers, $4 \pm 4 \%$; mineral mix, $12 \%$; soybean hulls, $5 \pm 4 \%$; molasses, $2 \%$; and tallow, $3 \%$.

${ }^{2} \mathrm{NFC}=100-[(\mathrm{NDF}-\mathrm{NDIN})+\mathrm{CP}+$ ether extract + ash $]$.

${ }^{3}$ Analyzed according to Hall (2000).

${ }^{4}$ Estimated according to NRC (2001).

at the same time as BW was recorded. The changes in BW and BCS were calculated for durations between measurements. Net energy balance (NEB) postcalving was calculated for periods wk 1 to 3 , wk 4 to 6 , and wk 6 to 9 according to NRC (2001). However, because it was not possible to separate losses due to body reserve mobilization from calving losses for the period from wk -3 to wk 1, the NEB for that period was not included in the analysis. Blood samples were collected on $1 \mathrm{~d}$ approximately $3 \mathrm{~h}$ postfeeding at the beginning of the experiment (wk -3 ) and the end of wk 1 and 3. Samples were stored on ice and subsequently centrifuged at $3,000 \times g$ for 15 min at room temperature to separate the plasma, and then stored at $-20^{\circ} \mathrm{C}$ until further processing. Plasma concentrations of BHBA, NEFA, glucose, and haptoglobin $(\mathbf{H p})$ were analyzed at the Animal Health Laboratories (University of Guelph) using a Cobas c501 analyzer (Roche, Mississauga, ON, Canada). Plasma glucose analysis was determined using the protocol and reagents recommended by Roche. Plasma contents of BHBA and NEFA were determined using agents obtained from Randox Laboratories (London, UK) according to the manufacturer's guidelines. Plasma content of $\mathrm{Hp}$ was determined using a modified protocol based on previously published methodology (Makimura and Suzuki, 1982; Skinner et al., 1991).
Data on cow health between wk -3 and wk 9 were obtained from on-farm computer records. Definitions for health events are included in the footnotes of Table 2 .

\section{Study 2: Effects on ATTD}

Apparent total-tract starch and NDF digestibility were assessed during from July through September 2012 (during the last block) using a subgroup of 21 cows (12 multiparous and 9 primiparous). A TMR sample was collected from a.m. feedings on d 59 and 60 postpartum. Seventeen TMR samples were collected in total as cows were aggregated in groups of 5 to 6 . Fecal samples were collected from individual cows intrarectally at 0900 and $1700 \mathrm{~h}$ on d 60 and at $1000 \mathrm{~h}$ on $\mathrm{d} 61$. Fecal and TMR samples were frozen at $-20^{\circ} \mathrm{C}$ for further analysis. Samples were analyzed for starch, NDF, lignin, and insoluble NDF (iNDF) using the Combs-Goeser method (Schalla et al., 2012). Apparent total-tract digestibility of NDF and starch were calculated, with lignin and iNDF as internal makers, using the following equation: Apparent nutrient digestibility $(\%)=100-\{100 \times($ TMR marker $/$ fecal maker $) \times[$ fecal nutrient content (\% of DM)/TMR nutrient content (\% of DM)]\}. The calculation was performed for each 
Table 2. Occurrence of disease in cows during the duration of the experiment (d 21 precalving through $\mathrm{d} 70$ postcalving), in which cows received either direct-fed microbial (DFM) supplement or placebo (control)

\begin{tabular}{lccc}
\hline & \multicolumn{2}{c}{ Disease occurrence, \% (no.) } & \\
\cline { 2 - 3 } Item $^{1}$ & Control & DFM & $P$-value $^{2}$ \\
\hline Removed & $0.0(0)$ & $5.0(3)$ & 0.12 \\
Sold & $1.7(1)$ & $3.3(2)$ & 0.62 \\
Died & $10.0(6)$ & $5.0(3)$ & 0.49 \\
Retained placenta & $15.0(9)$ & $15.0(9)$ & 0.97 \\
Milk fever & $10.0(6)$ & $1.7(1)$ & 0.11 \\
Metritis & $5.0(3)$ & $3.3(2)$ & 1.00 \\
Endometritis & $18.3(11)$ & $15.0(9)$ & 0.65 \\
Mastitis (first) & $20.0(12)$ & $23.3(14)$ & 0.62 \\
Ketosis (first) & $16.7(10)$ & $15.0(9)$ & 0.83 \\
Displaced abomasum & $8.3(5)$ & $5.0(3)$ & 0.72 \\
Lameness & $8.3(5)$ & $5.0(3)$ & 0.72 \\
Teat injury & $0.0(0)$ & $1.7(1)$ & 0.50 \\
Disease & $43.3(26)$ & $38.3(23)$ & 0.63 \\
Multiple illness & $23.3(14)$ & $21.7(13)$ & 0.87 \\
\hline
\end{tabular}

${ }^{1}$ Removed $=$ removed from the experiment before calving due to nonrelated reason, which included calving 2 wk before anticipated calving date, abortion, or teat injury; sold = culled from the herd during the experiment; died $=$ died during the experiment; retained placenta $=$ failure to pass the placenta within 24-h postcalving; milk fever $=$ a veterinary diagnosis of parturient hypocalcemia; metritis $=$ a veterinary diagnosis of uterine inflammation occurring before 15 DIM; endometritis = a veterinary diagnosis of uterine inflammation occurring beyond 14 DIM; mastitis = recorded with abnormal milk during the experiment; ketosis = a veterinary diagnosis based on reduced feed intake, testing positive for the milk ketone test, and the absence of any other disease; displaced abomasum $=$ a veterinary diagnosis of either right or left side abomasal displacement; lameness $=$ recorded as being lame or having a swollen limb or joint during the experiment; disease $=$ having at least one of retained placenta, milk fever, metritis, ketosis displaced abomasum, lameness, or pneumonia, excluding sold or died; multiple illness = having more than one of retained placenta, milk fever, metritis, ketosis displaced abomasum, lameness, or pneumonia, excluding sold or died.

${ }^{2}$ Analyzed using chi-squared statistics in a $2 \times 2$ table; Fisher's exact test was used when a count of observations was $<5$ in a cell of any given $2 \times 2$ table.

fecal replicate separately; however, the TMR nutrient content was the average of both TMR replicates.

\section{Statistical Analysis}

Weekly average of milk yields and DMI and weekly pooled milk components data were analyzed using Proc Mixed of SAS (SAS Institute, 2011) using a model that included treatment (DFM, placebo), parity (primiparous, multiparous), week (wk $-3, \ldots, 10$ or wk $1, \ldots, 10)$, block (calving season; $1, \ldots, 6)$, and their interactions as fixed effects. Week was used as a repeated measurement with cow as the subject. For each analyzed variable, cow was subjected to 5 covariance structures: compound symmetry, heterogeneous compound symmetry, autoregressive order 1 , heterogeneous autoregressive order 1 , and unstructured covariance structure. The covariance structure that gave the smallest Bayesian information criterion was used (Littell et al., 1996). Orthogonal polynomial contrasts were used to compare means of treatment and parity within week. Body weight, BCS, change in BW and BCS, and $\mathrm{NEB}$ data were analyzed using the same model as used for milk yield, DMI, and so on. Additionally, orthogonal polynomial contrasts were used to describe the linear and quadratic terms of week, week by treatment, and week by parity. Means and standard deviations of TMR ingredient compositions $(\mathrm{n}=7)$ and chemical analyses ( $\mathrm{n}=35$ ) were calculated for each TMR using Proc Means of SAS (SAS Institute, 2011). Disease outcome and the other variables were analyzed to test the effect of treatment using chi-squared statistics in a $2 \times$ 2 table. Fisher's exact test was used when counts of observations were $<5$ in a cell of any given $2 \times 2$ table. Starch and NDF ATTD values were averaged per cow and method (using lignin or iNDF as internal marker) and analyzed using Proc Mixed of SAS (SAS Institute, 2011) with a model that included the main effects of treatment (DFM, placebo), method, parity (multiparous, primiparous), and their interactions. Differences in fecal content of NDF, starch, lignin, and iNDF were tested using Proc TTEST of SAS (SAS Institute, 2011).

\section{RESULTS}

\section{Study 1}

DMI, Milk Yield, and Milk Components. The chemical composition of the dry- and lactating-cow TMR presented in Table 1 shows that our dietary 
balancing regimen was successful in minimizing the fluctuations in dietary composition commonly observed with seasonal variations.

Dry matter intake, milk yield, and milk components results are presented in Figure 1. Treatment had no significant effect on DMI $(\mathrm{kg} / \mathrm{d})$, milk yield $(\mathrm{kg} / \mathrm{d})$, or contents $(\mathrm{g} / 100 \mathrm{~g})$ and yields $(\mathrm{kg} / \mathrm{d})$ of milk components. The main effect of week was significant across all tested variables. The main effect of parity changed $(P$ $<0.001$ ) DMI, milk yield, and milk component yields (fat, protein, and lactose), but had no effect on either milk fat $(P=0.07)$ or milk protein $(P=0.08)$ percentage. We detected a significant interaction between parity and time on DMI, milk yield, lactose yield, and protein content, which implied that the difference between parities increased over time. Yields of $4 \% \mathrm{FCM}$ (NRC, 2001) $(P<0.001)$ and ECM (Tyrrell and Reid, 1965) $(P<0.001)$ reflected the response of fat yield, with multiparous cows having greater yields than primiparous cows. We observed no effect of block on DMI, milk yield, or milk components.

Differences between individual weeks across treatments were only detected during wk 1 , when multiparous cows receiving DFM had greater $(P<0.05)$ milk fat content, milk fat yield, and $4 \% \mathrm{FCM}$ and lower $(P<0.05)$ protein content compared with multiparous cows receiving placebo $(4.85 \pm 0.09$ vs. $4.58 \pm 0.09 \%$, $1.55 \pm 0.04$ vs. $1.41 \pm 0.04 \mathrm{~kg} / \mathrm{d}, 36.03 \pm 0.88$ vs. $33.65 \pm 0.86 \mathrm{~kg} / \mathrm{d}$, and $3.54 \pm 0.04$ vs. $3.69 \pm 0.04 \%$; respectively). However, ECM yield was not different between multiparous cows receiving DFM and placebo during wk 1 ( $39.18 \pm 0.91$ vs. $37.13 \pm 0.88 ; P=0.10)$.

$\boldsymbol{B} \boldsymbol{W}, \boldsymbol{B C S}$, and $\boldsymbol{N E B}$. Treatment did not affect $\mathrm{BW}$, change in BW, BCS, change in BCS, or NEB (Figure 2). However, the main effects of parity and both linear and quadratic week terms were significant. At the beginning of the experiment, average BW were $644 \pm 60$ and $760 \pm 65 \mathrm{~kg}$ and average BCS were 3.26 \pm 0.06 and $3.15 \pm 0.05$ for primiparous and multiparous cows, respectively. Net energy balance followed the same pattern as BW and BCS (Figure 3). Net energy balance was most negative during wh 1 to 3 and became less negative with increasing DIM.

Blood Metabolites. Treatment did not affect the blood metabolites measured in this experiment. We detected a quadratic time effect on NEFA with no differences due to parity. There was a significant parity effect and a linear increase in BHBA, with the increase being more pronounced in multiparous cows compared with primiparous cows (linear week by parity interaction; $P=0.003)$. We also observed a parity effect $(P<$ $0.001)$ and quadratic reduction over time $(P<0.001)$ in glucose (linear and quadratic time effect; $P<0.001$ ). There were parity $(P=0.02)$ and quadratic time effects
$(P<0.001)$ on Hp, without any interaction with any of the measured variables. The significant quadratic term indicated that the increase in Hp occurred during wk 1 postcalving.

\section{Study 2: ATTD}

Apparent total-tract digestibility of NDF and starch were evaluated for a subgroup of 21 cows from July through September 2012 (block 6). The TMR ( $\mathrm{n}=$ 17) content during that period of NDF, starch, lignin, and $\mathrm{iNDF}$ was $34 \pm 5,25 \pm 2,4 \pm 1$, and $14 \pm 2 \%$, respectively. Fecal contents of NDF, lignin, iNDF, and starch did not differ between treatments (Table 3). We detected no difference between the 2 methods (lignin vs. iNDF as an internal marker) used to assess ATTD. Additionally, the ATTD of measured nutrients did not differ between parities (primiparous vs. multiparous). Apparent total-tract digestibility (across methods) of starch was greater $(P=0.02)$ for cows supplemented with DFM (Table 3), but NDF digestibility did not differ between treatments.

\section{DISCUSSION}

\section{Study 1: Production, Blood, and Health Parameters}

In this experiment, the effects of DFM on DMI, milk yield, milk components, BW, BCS, NEB, and blood metabolites were evaluated. Supplementation with DFM had no effect on DMI or milk yield. Most changes detected in this study pertained to parity and time effects. Supplementing with DFM increased milk fat yield relative to placebo during wk 1 in multiparous cows, which translated into an increase in $4 \% \mathrm{FCM}$ (Figure 1). This increase in 4\% FCM was not associated with a significant increase in ECM during wk 1 in these cows $(39.18 \pm 0.91$ and $37.13 \pm 0.88 \mathrm{~kg} / \mathrm{d}$, respectively). This discrepancy was likely because of the simultaneous decrease in protein content observed in DFM cows during wk 1.

Net energy balance, which is the difference between energy intake (Mcal of $\mathrm{NE}_{\mathrm{L}}$ ) and energy utilization $\left(\mathrm{NE}_{\mathrm{L}}+\mathrm{NE}_{\mathrm{M}}\right)$, did not differ between treatments (Figure 3). However, NEB was most negative during wk 1 to 3 and less negative toward the end of study (a significant linear and quadratic effect of time). Primiparous cows had less negative NEB, given their lower production rate. Average BCS for enrolled cows at the beginning of the experiments was approximately 3.25 , and cows lost approximately 1 unit of BCS by the end of the experiment. The difference in BCS between multi- and primiparous cows was statistically significant but numerically small (Figure 2). Body weights of 

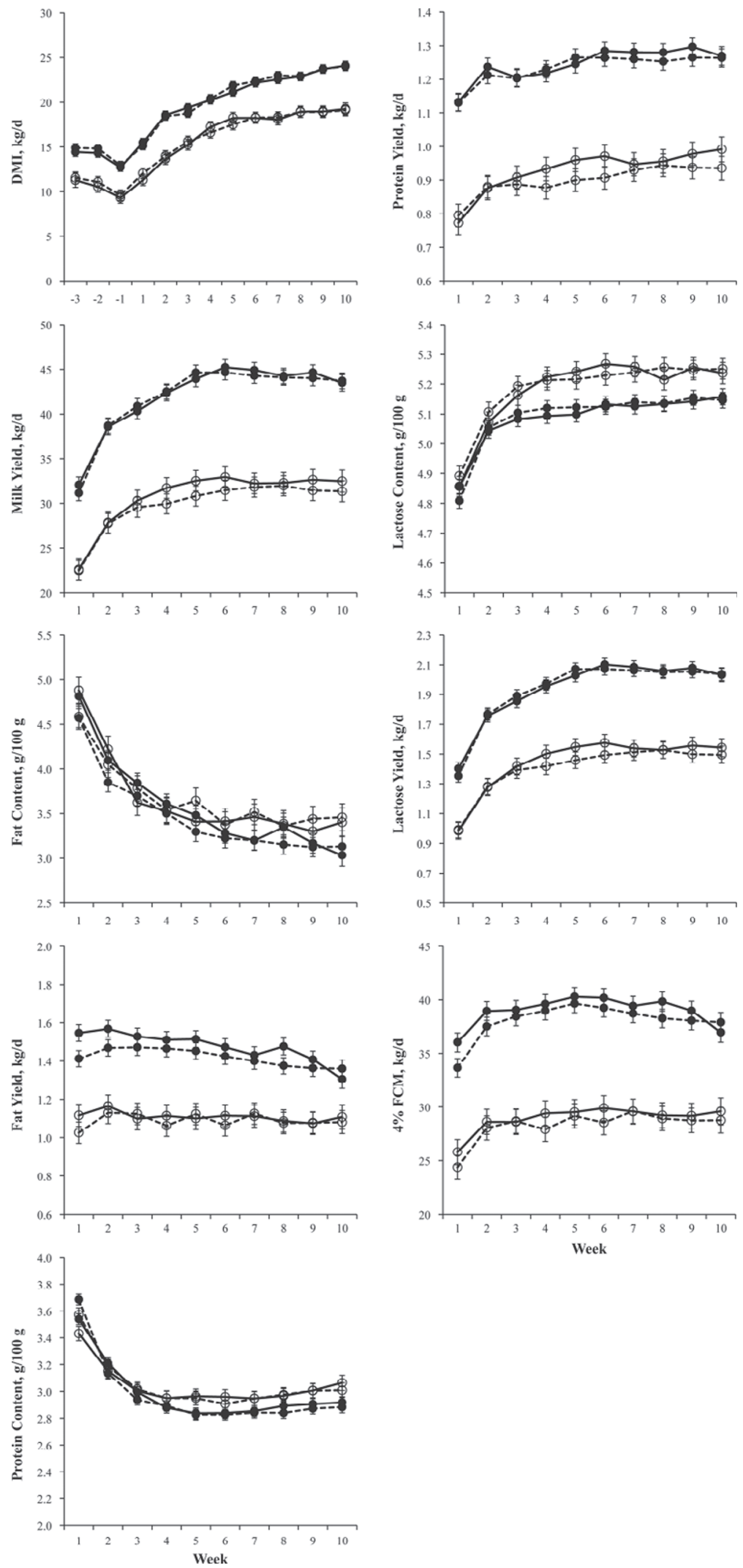

Figure 1. Least squares means of DMI, milk yield, and milk components. Cows (multiparous, •; primiparous, O) received either a direct-fed microbial supplement (DFM, solid line) or placebo (dashed line). 

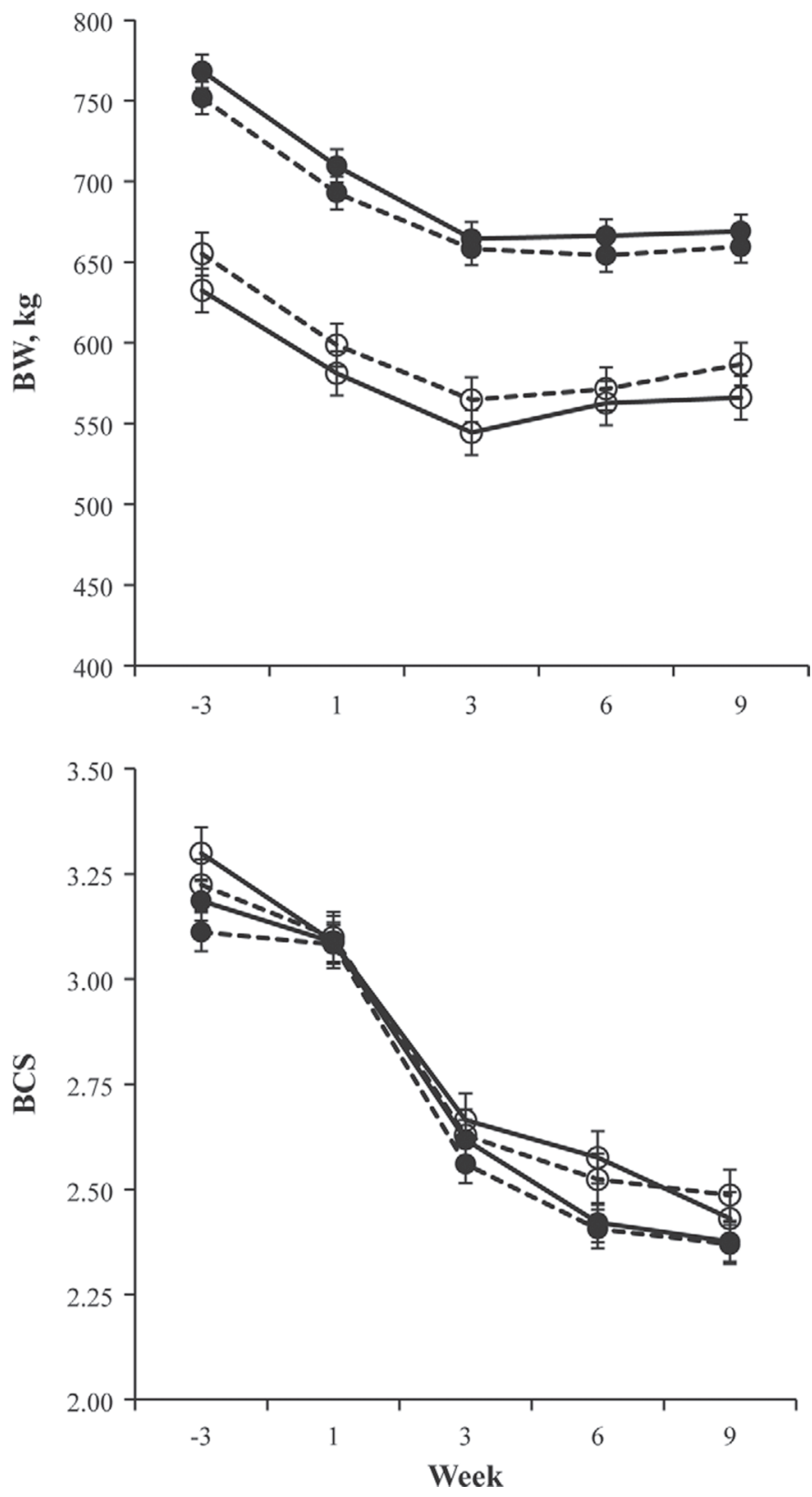

Figure 2. Least squares means of BW and BCS. Cows (multiparous, $\bullet$; primiparous, $\bigcirc$ ) received either a direct-fed microbial supplement (DFM, solid line) or placebo (dashed line).

multiparous cows were consistently greater than those of primiparous cows throughout the experiment. The changes in BCS and BW (data not shown) were most pronounced during the period from wk 1 to wk 3 . The change in BCS was consistent across parity but the change in BW was greater in multiparous compared with primiparous cows. During the first $3 \mathrm{wk}$, cows lost approximately 0.5 unit of BCS and $40 \mathrm{~kg}$ of BW. These numbers are in line with Fox et al. (1999), who defined the relationship between BW change and BCS

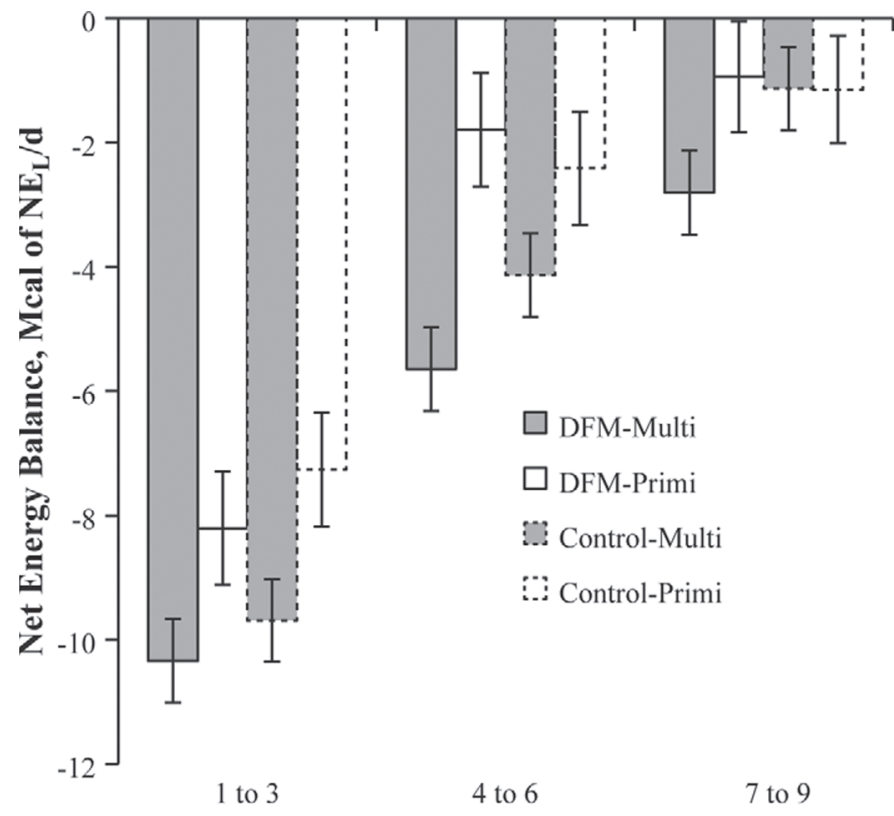

Week

Figure 3. Least squares means of net energy balance. Cows (multiparous, multi; primiparous, primi) received either a direct-fed microbial supplement (DFM) or placebo (control).

as $84.6 \mathrm{~kg} /$ unit of BCS. Cows continued to lose BCS after wk 3 and until the end of the experiment (wk 10), but at a slower rate (approximately 0.5 unit of BCS per $6 \mathrm{wk}$ ). Additionally, negative energy balance in dairy cows is characterized by unique changes in blood metabolites, such as increased NEFA and ketone bodies and reduction in glucose (Drackley, 1999). In this study, we detected a quadratic increase in plasma concentration of NEFA with a peak during wk 1 with no difference due to parity. The change in plasma concentration of BHBA was linear, with this increase being more pronounced in multiparous than in primiparous cows (linear time by parity interaction). The inverse relationship was observed in plasma concentration of glucose. The difference in milk yield observed between multiparous and primiparous cows reflected the difference in DMI. Other physiological factors play a significant role in determining the level of production of cows, such as mammary development and energy partitioning between growth and production (NRC, 2001).

In this study, we found no difference in disease occurrence between treatments (Table 2). The multiparous cows had 39 of the 49 disease cases and 24 of the 27 multiple illness cases. The disease cases in multiparous cows were equally distributed between treatments, with the exception of milk fever. Multiparous cows receiving placebo had 6 cases of milk fever, whereas cows receiving DFM had 1 case. 
Table 3. Fecal sample content (\% of DM) of NDF, starch, lignin, and insoluble NDF (iNDF) for the control (placebo) and DFM (supplementation with direct-fed microbial) treatment and apparent total-tract digestibility (ATTD) of NDF and starch (\% of total nutrients on a DM basis)

\begin{tabular}{lcccccc}
\hline & \multicolumn{2}{c}{ Control } & & \multicolumn{2}{c}{ DFM } & \\
\cline { 2 - 3 } \cline { 5 - 6 } Item & Mean & SE & & Mean & SE & $P$-value \\
\hline Fecal NDF, \% of DM & 53.64 & 2.39 & & 55.84 & 2.29 & 0.53 \\
Fecal starch, \% of DM & 1.39 & 0.25 & & 0.88 & 0.10 & 0.08 \\
Fecal lignin, \% of DM & 11.03 & 0.48 & & 11.78 & 0.52 & 0.31 \\
Fecal iNDF, \% of DM & 39.26 & 0.99 & & 39.03 & 0.63 & 0.84 \\
ATTD of NDF, \% & 41.72 & 1.98 & & 40.85 & 2.39 & 0.78 \\
ATTD of starch, \% & 97.87 & 0.24 & & 98.76 & 0.28 & 0.02 \\
\hline
\end{tabular}

Studies that examined the effect of DFM during the transition period are scarce. Those studies focused on measuring production parameters, rumen function, feed digestibility, and blood metabolites. An important source of variation across studies that should be considered is the differences in DFM types, doses, and method of delivery. The current study used a combination of LAB (E. faecium) and yeast (S. cerevisiae) and showed that DFM had no effect on any of the measured variables.

Our results agree with Savoini et al. (2000) and Francisco et al. (2002), who showed that DFM had no significant effects on milk production; however, both studies provided evidence of improved energy status. Savoini and colleagues (2000) demonstrated that supplementing dairy cows around calving with $15 \mathrm{~g} / \mathrm{d}$ of lactobacilli (L. plantatum, L. acidophilus, and L. casei) and E. faecium increased plasma glucose and reduced plasma NEFA at d 4 postcalving. Francisco et al. (2002) showed that supplementing Holstein dairy cows with Propionibacterium (17 g of culture/d) improved energy balance and feed efficiency during wk 1 postpartum, compared with nonsupplemented cows.

Nocek et al. (2003) investigated the effect of DFM [a combination of 2 Enterococcus strains $\left(5 \times 10^{9}\right.$ $\mathrm{cfu} / \mathrm{d})$ and $S$. cerevisiae $\left.\left(2 \times 10^{9} \mathrm{cfu} / \mathrm{d}\right)\right]$ fed from wk 3 precalving to wk 10 postpartum on performance of lactating Holstein cows. Results showed that DFM increased DMI (d 8 through 21 postpartum), milk production, and protein percentages (up to 70 DIM). The improved performance was associated, during the same period, with higher blood levels of glucose and insulin and lower serum levels of NEFA and BHBA. The authors suggested that the increased DMI postpartum improved the availability of glucose and reduced fatty acid mobilization. Our study used a similar feeding protocol (from wk -3 to wk 10) and a combination of Enterococcus and S. cerevisiae fed at the same rate, but we did not detect any overall difference in intake or milk production due to treatments except for an increase in $4 \% \mathrm{FCM}$ during wk1. In a subsequent study,
Nocek and Kautz (2006) further examined the effect of the same product on performance and health of transition Holstein cows. Cows supplemented with DFM consumed more DM than nonsupplemented cows (wk 1 precalving through wk 10 postcalving). Cows supplemented with DFM had higher milk production but lower milk fat percentage (4.44 vs. $4.76 \%$, respectively). Thus, DFM had no effect on 3.5\% FCM. In addition, Nocek and Kautz (2006) found no effect of DFM on BW or BCS changes. That study also showed no differences in detected cases of retained placenta, metritis, ketosis, or displaced abomasums. However, DFM-fed cows had lower blood BHBA levels during $\mathrm{d}-1$ and $\mathrm{d} 7$, and higher glucose levels during $d 7$, indicating a more positive energy balance.

Haptoglobin is an acute phase protein secreted by hepatic cells as a response to cytokines released from immune cells during inflammation, tissue damage, and infection (Murata et al., 2004). Haptoglobin may also be elevated during noninflammatory conditions such as pregnancy, parturition, and stress (Murata et al., 2004). Levels of Hp in serum can range from undetectable in healthy cows to $>1 \mathrm{~g} / \mathrm{L}$ in cows having claw disorders or metritis (Dubuc et al., 2010; Smith et al., 2010). Serum concentrations of Hp in the current study were the highest during wk 1 postcalving (Figure 4); however, these values were not different across treatments and considered within physiological ranges (Cray et al., 2009). Emmanuel et al. (2007b) demonstrated that feeding fed-lot steers a combination of E. faecium $\left(6 \times 10^{10} \mathrm{cfu} / \mathrm{d}\right)$ and $S$. cerevisiae $\left(6 \times 10^{10} \mathrm{cfu} / \mathrm{d}\right)$ increased plasma concentrations of serum amyloid A, lipopolysaccharide-binding protein, and $\mathrm{Hp}$, but had no effect on $\alpha_{1}$-acid glycoprotein. However, the authors reported no effect on any of the measured variables. Another study, Emmanuel et al. (2007a), confirmed that DFM can induce an inflammatory response in beef cattle. It is noteworthy that in the studies of Emmanuel and coworkers, beef cattle were fed a high-grain diet ( $\sim 90 \%)$, which alone is thought to trigger an inflammation response (Tourlomoussis et al., 2004). There 
is a paucity of data regarding the influences of DFM on immune responses and inflammation in bovine, and more studies are needed.

Live $S$. cerevisiae has been used in the ruminant industry as a standalone additive. The mechanisms proposed to explain the mode of action of $S$. cerevisiae within the rumen are mainly focused on optimizing fiber digestion [see reviews by Chaucheyras-Durand et al. (2008) and Robinson and Erasmus (2009)]. Yeast is thought to survive for a "short" period of time within the rumen by utilizing traces of dissolved oxygen. Yeast
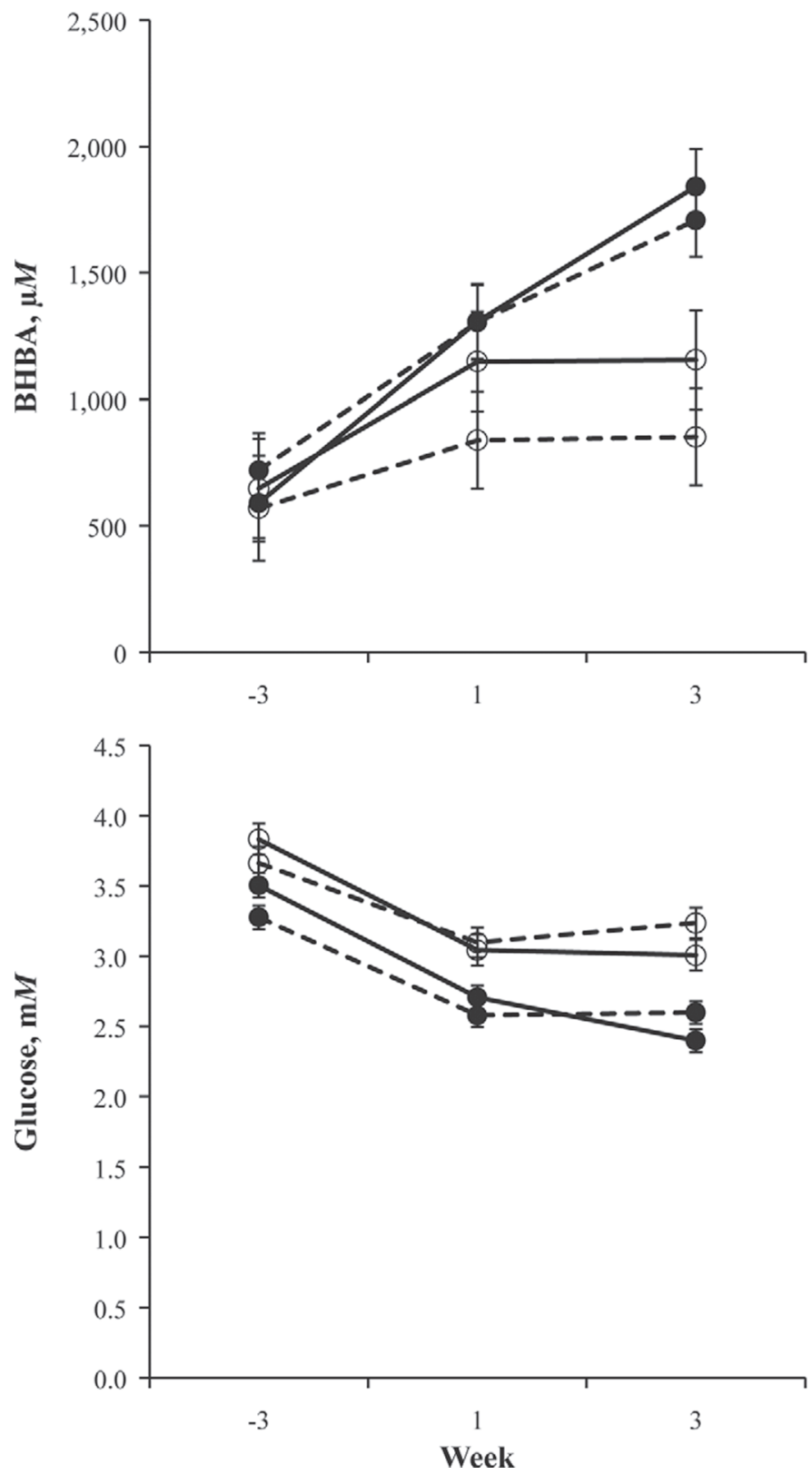

can then be directly involved in fiber digestion and (or) can create an optimal anaerobic environment for bacterial growth. Yeast is also proposed to create optimal growth conditions for bacteria by preventing the accumulation of lactic acid within the rumen (Nocek, 1997). Our recent study (AlZahal et al., 2013a,b) demonstrated that $S$. cerevisiae fed to mid-lactation dairy cows at a rate of $8 \times 10^{10} \mathrm{cfu} / \mathrm{d}$ prevented the decrease in milk yield and intake and alleviated ruminal $\mathrm{pH}$ when cows were challenged with SARA and increased fiber-degrading microorganisms compared with control
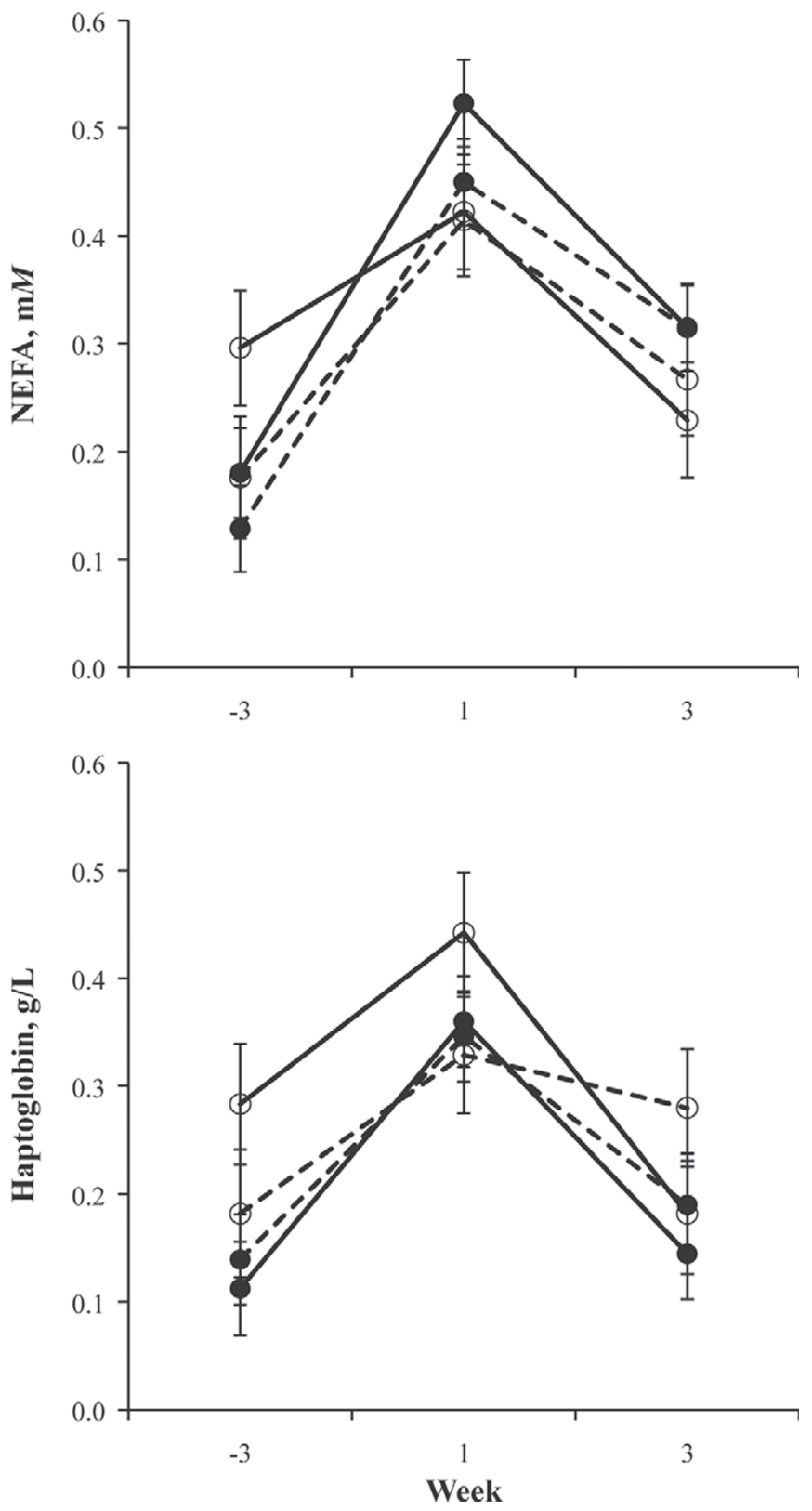

Figure 4. Least squares means of serum concentrations of BHBA, glucose, NEFA, and haptoglobin. Cows (multiparous, received either a direct-fed microbial supplement (DFM, solid line) or placebo (dashed line). 
cows. Nonetheless, the synergy between S. cerevisiae and LAB or LUB is not understood. Recently, Chiquette et al. (2012) tested the effect of E. faecium (2.5 $\left.\times 10^{9} \mathrm{cfu} / \mathrm{g}\right)$ separately or in combination with either S. cerevisiae $\left(1 \times 10^{9} \mathrm{cfu} / \mathrm{g}\right)$ or $L$. lactis $\left(2.8 \times 10^{9}\right.$ $\mathrm{cfu} / \mathrm{g})$ on ruminal $\mathrm{pH}$ of lactating cows induced with SARA. That DFM was infused via cannula at a rate of $80 \mathrm{mg} / \mathrm{kg}$ of DMI. Results showed that all 3 treatments resulted in a smaller decrease in milk production during SARA challenge compared with control. However, cows receiving $E$. faecium in combination with $S$. cerevisiae or Lactococcus lactis had a higher ruminal $\mathrm{pH}$ during the SARA challenge compared with those receiving E. faecium alone. Furthermore, those authors demonstrated that only E. faecium + S. cerevisiae prevented the decrease in ruminal vitamin $B_{12}$. The work of Chiquette et al. (2012) suggested that supplementing DFM combinations can be more effective during dietary challenges leading to SARA.

\section{Study 2: ATTD}

Increased total-tract starch digestibility is reported to increase milk and protein yields and feed efficiency (Firkins et al., 2001). Total-tract digestibility can be assessed by using total collection of feces or using an external or internal marker that is added to the feed. Both methods, however, require measuring feed and fecal starch and marker content. The use of lignin as an internal marker is common and practical. However, lignin should be used with caution in digestibility studies as it can be partially digested (Fahey and Jung, 1983), mainly in less lignified grass-based forages. Recently, a method was developed to use iNDF as an internal marker, which is quantified after $120 \mathrm{~h}$ of in vitro incubation in a rumen-inoculated medium (Schalla et al., 2012). Our results indicated no difference between methods in assessing total-tract digestibility, likely because of the level of lignification and (or) the ensiling process of the forages used in the current study. Total-tract digestibility is affected by several factors such as grain processing and storage (Firkins et al., 2001) and usually ranges between 70 and $99 \%$, while fecal starch content ranges from 0 to $5 \%$ (Fredin et al., 2014). In the current study, the values of starch digestibility and fecal starch were within these ranges. However, the DFM cows had greater starch ATTD, and this increase was reflected by a tendency for those cows to have lower fecal starch content compared with the control cows (Table 3). Reports on the effect of Enterococcus on ATTD of starch are scarce but, recently, Solórzano and Vale (2011) reported, using a similar DFM product, an increase in ATTD of starch from 87.2 to $99.5 \%$. This increase was associated with increases in DMI and milk production.
The increase in ATTD detected by Solórzano and Vale (2011) was greater than that found in the current study (12.3 vs. 1 unit, respectively). The difference between the 2 studies is likely due to the much lower ATTD of the control diet used by Solórzano and Vale (2011) compared with the current study ( 87.2 vs. $97.87 \%$ ). In the current study, ATTD of NDF was not affected by DFM supplementation and was approximately $41 \%$. The main effect of parity and method did not influence either starch or NDF digestibility.

As previously discussed, modes of action of DFM are not well defined. The most common hypothesis is that LUB and LAB, separately or in combination, can modulate lactate metabolism and improve rumen function. However, the fact that some LAB species are naturally occurring in the gut (and evident in the feces) suggests a beneficial role for LAB postruminally. Such benefits are thought to improve gut health and immune responses (Seo et al., 2010; McAllister et al., 2011). The acute phase protein (Hp) measured in study 1 showed did not differ between treatments, which indicated no effect of this DFM on inducing or mitigating a systemic immune response.

The current investigation (study 2) reported an increase in starch digestibility with DFM supplementation but provided no evidence on site of digestion. The lack of difference in NDF digestibility may indicate similar ruminal conditions among treatments and that DFM may have acted postruminally. Although the increase in ATTD in this experiment was numerically small and did not result in changes in cow performance, the results are encouraging for future studies to examine the effect of DFM on gastrointestinal digestibility and health using different dietary scenarios such as a SARA challenge. Studies should focus on uncovering the mode of action of DFM, and should include assessment of the microbial population structure of the gastrointestinal tract and measurement of changes in gene expression in the gastrointestinal tract pertaining to nutrient metabolism, barrier function, and innate and adaptive immune responses.

\section{ACKNOWLEDGMENTS}

The authors thank Laura Wright and the staff of the Elora Dairy Research Centre (University of Guelph, ON, Canada) for their technical assistance, and Chr. Hansen Ltd. (Milwaukee, WI) and Ontario Ministry of Agriculture and Food (Guelph, ON, Canada) for their financial support.

\section{REFERENCES}

AlZahal, O., L. Dionissopoulos, N. D. Walker, and B. W. McBride. 2013a. Effect of Saccharomyces cerevisiae on ruminal microbial 
community during subacute ruminal acidosis. Page 26 in Symposium on Gut Health in Production of Food Animals, Kansas City, MO. Federation of Animal Science Societies, Champaign, IL.

AlZahal, O., E. Kebreab, J. France, and B. W. McBride. 2007. A mathematical approach to predicting biological values from ruminal pH measurements. J. Dairy Sci. 90:3777-3785.

AlZahal, O., M. M. Or-Rashid, S. L. Greenwood, M. S. Douglas, and B. W. McBride. 2009. The effect of dietary fiber level on milk fat concentration and fatty acid profile of cows fed diets containing low levels of polyunsaturated fatty acids. J. Dairy Sci. 92:1108-1116.

AlZahal, O., M. M. Or-Rashid, S. L. Greenwood, and B. W. McBride. 2010. Effect of subacute ruminal acidosis on milk fat concentration, yield and fatty acid profile of dairy cows receiving soybean oil. J. Dairy Res. 77:376-384.

AlZahal, O., N. Walker, and B. W. McBride. 2013b. Saccharomyces cerevisiae can alleviate the impact of subacute ruminal acidosis in dairy cattle. Page 401 in 64th Annu. Mtg. Europ. Fed. Anim. Sci., Nantes, France. EAAP, Rome, Italy.

AOAC International. 1996. Official Methods of Analysis. 16th ed. AOAC International, Arlington, VA.

Berndtson, W. E. 1991. A simple, rapid and reliable method for selecting or assessing the number of replicates for animal experiments. J. Anim. Sci. 69:67-76.

Blomberg, L., A. Henriksson, and P. L. Conway. 1993. Inhibition of adhesion of Escherichia coli K88 to piglet ileal mucus by Lactobacillus spp. Appl. Environ. Microbiol. 59:34-39.

Casaus, P., T. Nilsen, L. M. Cintas, I. F. Nes, P. E. Hernández, and H. Holo. 1997. Enterocin B, a new bacteriocin from Enterococcus faecium T136 which can act synergistically with enterocin A. Microbiology 143:2287-2294.

Chaucheyras-Durand, F., N. D. Walker, and A. Bach. 2008. Effects of active dry yeasts on the rumen microbial ecosystem: Past, present and future. Anim. Feed Sci. Technol. 145:5-26.

Chiquette, J. 2009. Evaluation of the protective effect of probiotics fed to dairy cows during a subacute ruminal acidosis challenge. Anim. Feed Sci. Technol. 153:278-291.

Chiquette, J., J. Lagrost, C. L. Girard, S. Li, J. C. Plaizier, and G. Talbot. 2012. Combination of bacterial and yeast probiotics: A step forward to unravel their mode of action. J. Dairy Sci. 95(Suppl. 2):120. (Abstr.)

Cray, C., J. Zaias, and N. H. Altman. 2009. Acute phase response in animals: A review. Comp. Med. 59:517-526.

Drackley, J. K. 1999. Biology of dairy cows during the transition period: The final frontier? J. Dairy Sci. 82:2259-2273.

Dubuc, J., T. F. Duffield, K. E. Leslie, J. S. Walton, and S. J. LeBlanc. 2010. Risk factors for postpartum uterine diseases in dairy cows. J. Dairy Sci. 93:5764-5771.

Emmanuel, D. G. V., A. Jafari, K. A. Beauchemin, J. A. Z. Leedle, and B. N. Ametaj. 2007a. Feeding a combination of lactate-utilizing and lactate-producing bacteria modulates acute phase response in feedlot steers. Can. J. Anim. Sci. 87:251-257.

Emmanuel, D. G. V., A. Jafari, K. A. Beauchemin, J. A. Z. Leedle, and B. N. Ametaj. 2007b. Feeding live cultures of Enterococcus faecium and Saccharomyces cerevisiae induces an inflammatory response in feedlot steers. J. Anim. Sci. 85:233-239.

Fahey, G. C., and H. G. Jung. 1983. Lignin as a marker in digestion studies: A review. J. Anim. Sci. 57:220-225.

Fairfield, A. M., J. C. Plaizier, T. F. Duffield, M. I. Lindinger, R. Bagg, P. Dick, and B. W. McBride. 2007. Effects of prepartum administration of a monensin controlled release capsule on rumen $\mathrm{pH}$, feed intake, and milk production of transition dairy cows. J. Dairy Sci. 90:937-945.

Firkins, J., M. Eastridge, N. St-Pierre, and S. Noftsger. 2001. Effects of grain variability and processing on starch utilization by lactating dairy cattle. J. Anim. Sci. 79(E-Suppl.):E218-E238.

Fox, D. G., M. E. van Amburgh, and T. P. Tylutki. 1999. Predicting requirements for growth, maturity, and body reserves in dairy cattle. J. Dairy Sci. 82:1968-1977.

Francisco, C. C., C. S. Chamberlain, D. N. Waldner, R. P. Wettemann, and L. J. Spicer. 2002. Propionibacteria fed to dairy cows: Effects on energy balance, plasma metabolites and hormones, and reproduction. J. Dairy Sci. 85:1738-1751.

Fredin, S. M., L. F. Ferraretto, M. S. Akins, P. C. Hoffman, and R. D. Shaver. 2014. Fecal starch as an indicator of total-tract starch digestibility by lactating dairy cows. J. Dairy Sci. 97:1862-1871.

Fuller, R. 1989. Probiotics in man and animals. J. Appl. Bacteriol $66: 365-378$.

Hall, M. B. 2000. Starch gelatinization and hydrolysis method. Pages 29-38 in Neutral Detergent Soluble Carbohydrates, Nutritional Relevance and Analysis-A Laboratory Manual. Department of Animal Science, University of Florida, Gainesville.

Isolauri, E., Y. Sutas, P. Kankaanpaa, H. Arvilommi, and S. Salminen. 2001. Probiotics: Effects on immunity. Am. J. Clin. Nutr. 73:444S-450S

Jin, L. Z., R. R. Marquardt, and X. Zhao. 2000. A strain of Enterococcus faecium (18C23) inhibits adhesion of enterotoxigenic Escherichia coli K88 to porcine small intestine mucus. Appl. Environ. Microbiol. 66:4200-4204.

Khafipour, E., D. O. Krause, and J. C. Plaizier. 2009a. A grain-based subacute ruminal acidosis challenge causes translocation of lipopolysaccharide and triggers inflammation. J. Dairy Sci. 92:10601070.

Khafipour, E., S. C. Li, J. C. Plaizier, and D. O. Krause. 2009b. Rumen microbiome composition determined using two nutritional models of subacute ruminal acidosis. Appl. Environ. Microbiol. $75: 7115-7124$

Kung, L., Jr. 1999. Direct-fed microbial and enzyme feed additives Pages 69-77 in Direct-Fed Microbial, Enzyme and Forage Additive Compendium. S. Muirhead, ed. The Miller Publishing Co., Minnetoka, MN.

Kung, L., Jr., and A. O. Hession. 1995. Preventing in vitro lactate accumulation in ruminal fermentation by inoculation with Megasphera elsdenii. J. Anim. Sci. 73:250-256.

Lauková, A., M. Mareková, and P. Javorský. 1993. Detection and antimicrobial spectrum of a bacteriocin-like substance produced by Enterococcus faecium CCM4231. Lett. Appl. Microbiol. 16:257260

Lewenstein, A., G. Frigerio, and M. Moroni. 1979. Biological properties of SF68, a new approach for the treatment of diarrhoeal diseases. Curr. Ther. Res. 26:967-981.

Li, S., E. Khafipour, D. O. Krause, A. Kroeker, J. C. RodriguezLecompte, G. N. Gozho, and J. C. Plaizier. 2012. Effects of subacute ruminal acidosis challenges on fermentation and endotoxins in the rumen and hindgut of dairy cows. J. Dairy Sci. 95:294-303.

Li, S., J. C. Plaizier, E. Khafipour, and D. O. Krause. 2011. Effects of subacute ruminal acidosis (SARA) challenges on bacteria in the digestive tract of dairy cows. J. Dairy Sci. 94(E-Suppl. 1):624. (Abstr.)

Licitra, G., T. M. Hernandez, and P. J. VanSoest. 1996. Standardization of procedures for nitrogen fractionation of ruminant feeds. Anim. Feed Sci. Technol. 57:347-358.

Littell, R. C., G. A. Milliken, W. W. Stroup, and R. D. Wolfinger 1996. SAS System for Mixed Models. SAS Institute Inc., Cary, NC

Makimura, S., and N. Suzuki. 1982. Quantitative determination of bovine serum haptoglobin and its elevation in some inflammatory diseases. Nippon Juigaku Zasshi 44:15-21.

McAllister, T. A., K. A. Beauchemin, A. Y. Alazzeh, J. Baah, R. M. Teather, and K. Stanford. 2011. Review: The use of direct fed microbials to mitigate pathogens and enhance production in cattle. Can. J. Anim. Sci. 91:193-211.

Mertens, D. R. 1997. Creating a system for meeting the fiber requirements of dairy cows. J. Dairy Sci. 80:1463-1481.

Murata, H., N. Shimada, and M. Yoshioka. 2004. Current research on acute phase proteins in veterinary diagnosis: An overview. Vet. J. $168: 28-40$

Nigutova, K., M. Morovsky, P. Pristas, R. M. Teather, H. Holo, and P. Javorsky. 2007. Production of enterolysin A by rumen Enterococcus faecalis strain and occurrence of enlA homologues among ruminal Gram-positive cocci. J. Appl. Microbiol. 102:563-569.

Nocek, J. E. 1997. Bovine acidosis: Implications on laminitis. J. Dairy Sci. $80: 1005-1028$. 
Nocek, J. E., and W. P. Kautz. 2006. Direct-fed microbial supplementation on ruminal digestion, health, and performance of pre- and postpartum dairy cattle. J. Dairy Sci. 89:260-266.

Nocek, J. E., W. P. Kautz, J. A. Z. Leedle, and J. G. Allman. 2002 Ruminal supplementation of direct-fed microbials on diurnal $\mathrm{pH}$ variation and in situ digestion in dairy cattle. J. Dairy Sci. 85:429-433.

Nocek, J. E., W. P. Kautz, J. A. Z. Leedle, and E. Block. 2003. Directfed microbial supplementation on the performance of dairy cattle during the transition period. J. Dairy Sci. 86:331-335.

NRC. 2001. Nutrient Requirements of Dairy Cattle. 7th rev. ed. National Academies Press, Washington, DC.

Oetzel, G. R. 2000. Clinical aspects of ruminal acidosis in dairy cattle. Pages 46-53 in American Association of Bovine Practitioners, Rapid City, SD. Am. Assoc. Bovine Pract., Auburn, AL.

Penner, G. B., K. A. Beauchemin, and T. Mutsvangwa. 2007. Severity of ruminal acidosis in primiparous Holstein cows during the periparturient period. J. Dairy Sci. 90:365-375.

Plaizier, J. C., D. O. Krause, G. N. Gozho, and B. W. McBride. 2008. Subacute ruminal acidosis in dairy cows: The physiological causes, incidence and consequences. Vet. J. 176:21-31.

Pridmore, R. D., A. C. Pittet, F. Praplan, and C. Cavadini. 2008 Hydrogen peroxide production by Lactobacillus johnsonii NCC 533 and its role in anti-Salmonella activity. FEMS Microbiol. Lett. 283:210-215.

Reynolds, C. K. 2006. Production and metabolic effects of site of starch digestion in dairy cattle. Anim. Feed Sci. Technol. 130:78-94.

Robinson, R. H., and L. J. Erasmus. 2009. Effects of analyzable diet components on responses of lactating dairy cows to Saccharomyces cerevisiae based yeast products: A systematic review of the literature. Anim. Feed Sci. Technol. 149:185-198.

SAS Institute. 2011. SAS/STAT User's Guide. Release 9.3. SAS Inst. Inc., Cary, NC.

Savoini, G., G. Mancin, S. S. Rossi, A. Grittini, A. Baldi, and V. DellOrto. 2000. Administration of lactobacilli in transition [peripartum] cows: Effects on blood level of glucose, beta-hydroxyybutyrate, NEFA, and on milk yield. Obiettive e Documenti Veterinari $21: 65-70$.
Schalla, A., L. Meyer, Z. Meyer, S. Onetti, A. Schultz, and J. Goeser 2012. Hot topic: Apparent total-tract nutrient digestibilities measured commercially using 120-hour in vitro indigestible neutral detergent fiber as a marker are related to commercial dairy cattle performance. J. Dairy Sci. 95:5109-5114.

Seo, J. K., S. W. Kim, M. H. Kim, S. D. Upadhaya, D. K. Kam, and J. K. Ha. 2010. Direct-fed microbials for ruminant animals. Asianaustralas. J. Anim. Sci. 23:1657-1667.

Skinner, J. G., R. A. Brown, and L. Roberts. 1991. Bovine haptoglobin response in clinically defined field conditions. Vet. Rec 128:147-149.

Smith, B. I., J. Kauffold, and L. Sherman. 2010. Serum haptoglobin concentrations in dairy cattle with lameness due to claw disorders. Vet. J. 186:162-165.

Solórzano, L. C., and S. N. Vale. 2011. Synbiotic supplementation for multiparous cows improves starch digestibility. Rev. Arg. Prod. Anim. 31(Suppl. 1):400. (Abstr.)

Steele, M. A., J. Croom, M. Kahler, O. AlZahal, S. E. Hook, K. Plaizier, and B. W. McBride. 2011. Bovine rumen epithelium undergoes rapid structural adaptations during grain-induced subacute ruminal acidosis. Am. J. Physiol. Regul. Integr. Comp. Physiol. 300:R1515-R1523.

Tourlomoussis, P., P. D. Eckersall, M. M. Waterson, and S. Buncic 2004. A comparison of acute phase protein measurements and meat inspection findings in cattle. Foodborne Pathog. Dis. 1:281-290.

Tyrrell, H. F., and J. T. Reid. 1965. Prediction of the energy value of cow's milk. J. Dairy Sci. 48:1215-1223.

Wildman, E. E., G. M. Jones, P. E. Wagner, R. L. Boman, H. F. Troutt, and T. N. Lesch. 1982. A dairy-cow body condition scoring system and its relationship to selected production characteristics. J. Dairy Sci. 65:495-501.

Yoon, I. K., and M. D. Stern. 1995. Influence of direct-fed microbials on ruminal microbial fermentation and performance of ruminants: A review. Asian-australas. J. Anim. Sci. 8:533-555.

Zheng, H., S. Qi, J. Li, Z. Yang, and Y. Wang. 2012. Effect of a probiotic Enterococcus faecium strain on the number of intestinal mucosal immune cells of young yaks. J. Anim. Vet. Adv. 11:3887-3893. 